\title{
Frugal Product Innovation in Urban Affordable housing - With Special Reference to the Bottom of the Economic Pyramid
}

\author{
Dr. Lakshmi Jagannathan Prof. Roshny Unnikrishnan
}

\begin{abstract}
This study is conducted to unearth the Frugal Product Innovation in the value chain to enable affordable housing solution at the Bottom of the economic pyramid. The Demand and supply factors are unearthed from the study as Affordability, Critical considerations of customers like Know Your Customer (KYC) and Rebuilding the value chain from traditional concepts using the concept of Frugal product Innovation. Factor Analysis using data from Primary survey reveals that price and Ease of Finance remain most Critical considerations in Affordable Housing for the Bottom of the Economic Pyramid.The study concludes by suggesting further process innovations in Affordable housing and states that eradicating poverty at the Bottom of the economic Pyramid is more effective in the long run than temporarily providing affordable housing solutions.
\end{abstract}

Keywords: Frugal Product Innovation, Urban Affordable Housing, Bottom of the Economic Pyramid, Factor Analysis

\section{Introduction}

The world population is over 7 billion, the fact remains that the majority of this population is not included financially and socially, living in poverty. This segment who are not perceived as profitable customers are in fact "resilient entrepreneurs and value conscious consumers". The need of the day involve partnering with them to innovate and partner in win-win scenarios where poor are actively engaged and companies providing products and services to them are profitable. (Prahlad\&Hart 2002).A major need for frugal innovation exists in the providing housing solutions and innovations in value chain in affordable housing for the bottom of the economic pyramid.

To provide housing to all irrespective of income problems unique to affordable housing needs to be addressed (Brian Rogal 2006). 15\% of India's urban population lives in slum settlements. The $11^{\text {th }}$ five year plan had estimated the shortage of about 24 million housing units and 99 percent of the shortage is with respect to the lower income population or the bottom of the economic pyramid.

According to KPMG survey on "Affordable Housing - A key growth driver in the real estate sector?" affordable housing is defined in terms of three main parameters, namely income level, size of dwelling unit and affordability.

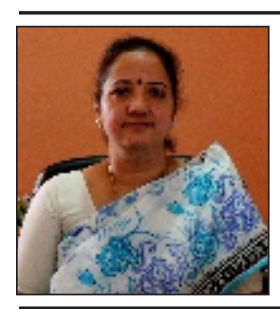

Dr. Lakshmi Jagannathan

Professor \& Head of the MBA Dept.

Dayananda Sagar College of Engineering Bangalore - 560078

Mobile: 9449963390

Email: Lakshmi.quality@gmail.com

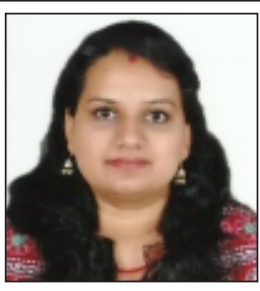

Prof. Roshny Unnikrishnan

Assistant Professor The Oxford College Of Business Management,

Bangalore - 560 102. Mobile: 9945400933 Email: Roshnyunnikrishnan@yahoo.co.in 
Exhibit No: 1 Defining Affordable housing

\begin{tabular}{|c|c|c|c|}
\hline & Income Level & $\begin{array}{c}\text { Size of Dwelling } \\
\text { Unit }\end{array}$ & Affordability \\
\hline EWS* & $\begin{array}{l}<\text { INR } 1.5 \text { lacs per } \\
\text { annum }\end{array}$ & Upto 300 sq. $\mathrm{ft}$. & \multirow{3}{*}{$\begin{array}{l}\text { EMI to Monthly Income } \\
\text { - } 30 \text { to } 40 \text { percent } \\
\text { - } \text { House Price to } \\
\text { Annual Income } \\
\text { Ratio Less than } \\
5.1\end{array}$} \\
\hline LIG ** & $\begin{array}{l}\text { INR } 1.5 \text { to } 3 \text { lacs per } \\
\text { annum }\end{array}$ & 300 to $600 \mathrm{sq} . \mathrm{ft}$. & \\
\hline $\mathrm{MIG}^{* * *}$ & $\begin{array}{l}\text { INR } 3 \text { to } 10 \text { lacs per } \\
\text { annum }\end{array}$ & 600 to 1200 sq. $\mathrm{ft}$. & \\
\hline
\end{tabular}

*Economically Weaker Section **Lower Income Group ***Middle Income Group Source: KPMG Analysis, Knight Frank

One of the challenges unique to the segment is that of frugal product innovation, the challenge of keeping affordable housing affordable in terms of financial burden on the target segment while other characteristics and value added to individual housing unit needs to be retained to meet popular expectations. This challenge becomes all the more relevant to the Bottom of the Economic Pyramid given the unique constraints of the segment.

\section{Research Methodology}

\section{Statement of the problem}

The housing sector across the world is characterised by demand and supply mis-match. These mis-matches also indicate that tremendous business opportunities exist in the affordable housing area.

\section{Objectives}

The study aims to unearth the challenges and solutions of providing affordable housing for the Bottom of the Economic Pyramid.(BoP)

The factors relevant to the BoP are unearthed through Factor Analysis based on factors such as Location, Civic Amenities, Easy Finance, Easy Regulations, Affordable Price, and Social Inclusion relevant to the income segment.
The objective is also to suggest measures toward improving Public Private partnership to provide affordable housing solutions by leveraging factors like Land Availability, Financing, Cost of Prodution, Connectivity and Infrastructure and improved focus on Economically Weaker Sections (EWS)

\section{Research Design}

The objectives are met with a conceptual study on the relevant literature to understand past studies and findings.

Factor analysis is conducted on a sample of 250 respondents from Bangalore urban to analyze the comparative relevance of factors in Affordable housing.

\section{Literature review}

Companies assume that the Bottom of the Economic Pyramid customers is not a profitable and attractive market. The Bottom of the Economic Pyramid market as per their estimate consists of about 4 billion people who are underserved by the Multinational corporations due to the income inequality between the segments. (Prahlad and Hart - 2002) 


\section{Exhibit No:2 Purchasing power at the Bottom of the Economic Pyramid}

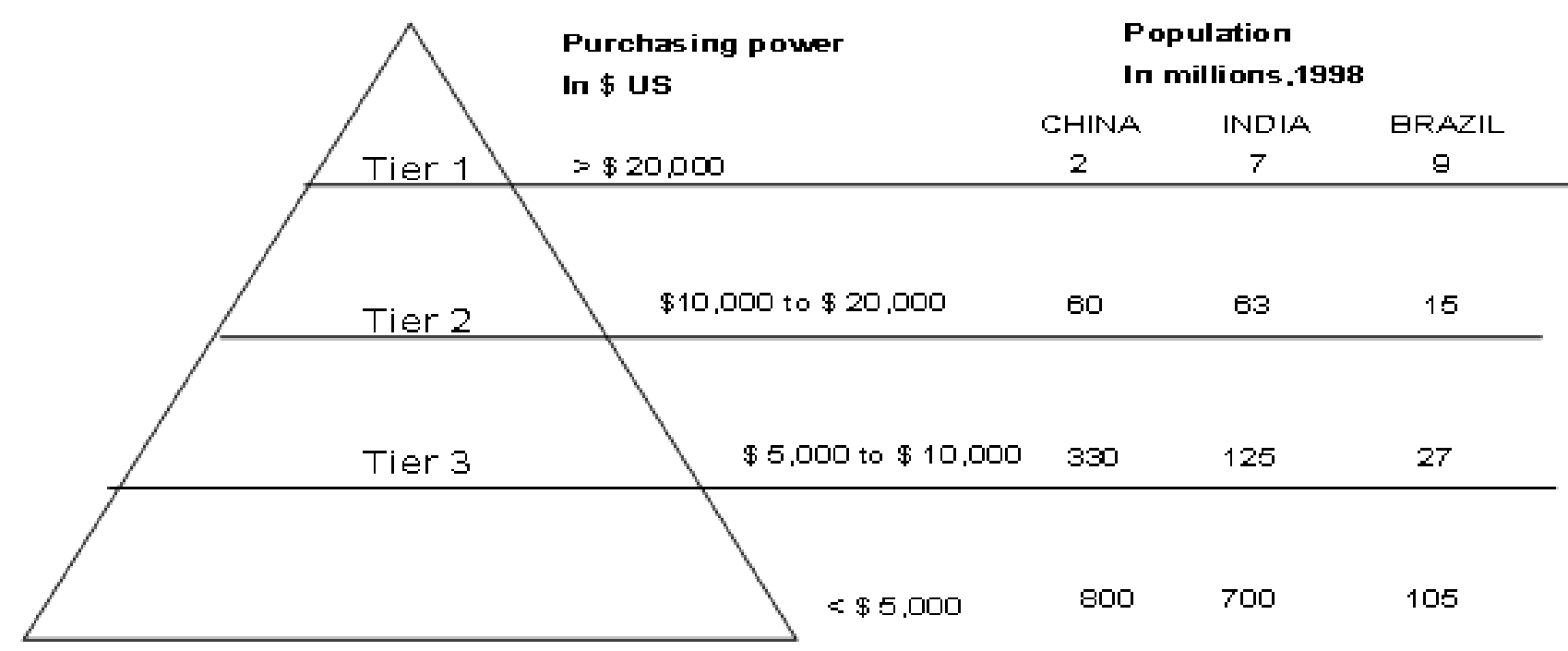

Source: "The end of corporate imperialism" Harvard Business Review July - August 1998

Undesirable inclusion and exclusion exists at the Bottom of the Economic Pyramid by the Multinational companies. Inclusion is seen as "marketing products that are not likely to enhance their wellbeing or products that are likely to be abused by them" and exclusion as "not offering products that are likely to enhance their wellbeing". (Anand Kumar Jaiswal -2007). The concept of eradicating poverty through profits is said to be almost a mirage. The purchasing power parity of the Bottom of the Economic Pyramid customers is substantially lower than as claimed by Dr C. K Prahlad. The cost of serving the Bottom of the Economic Pyramid market can be very high given the high cost of distribution and logistics management given the fact that the Bottom of the Economic Pyramid customers are 'geographically dispersed and culturally heterogeneous.' The benefits of economies of scale are not derived because of weak infrastructure and relatively minuscule sizes of the transactions. Companies are seen to prefer small packages only to build a brand and as part of the promotional strategies. Increased emphasis by
MNC's on Bottom of the Economic Pyramid customer leads to exploitation. The poor should be perceived not as customers but as producers and the concept of buying from the poor should be emphasized. "The only way to alleviate poverty is to raise the real income of the poor and suggest creating employment and government intervention as some steps for achieving the same."(Aneelkarnani - 2007)

The right value propositions needs to be delivered in cash constrained emerging markets for delivering value to the bottom of the pyramid consumers, hence the need of frugal innovation. Whereas innovation in most contexts takes the form of advanced products with richer features, frugal product innovation meets the needs of "millions in developing markets that do not have millions". The following variables are identified as relevant to frugal innovation- Affordability, Know your customer and building a new value chain. The following toolkit is proposed to guide company's efforts in frugal innovation. (Kaushik Mukerjee 2012) 
Exhibit No: 3 Toolkit for Frugal Innovation

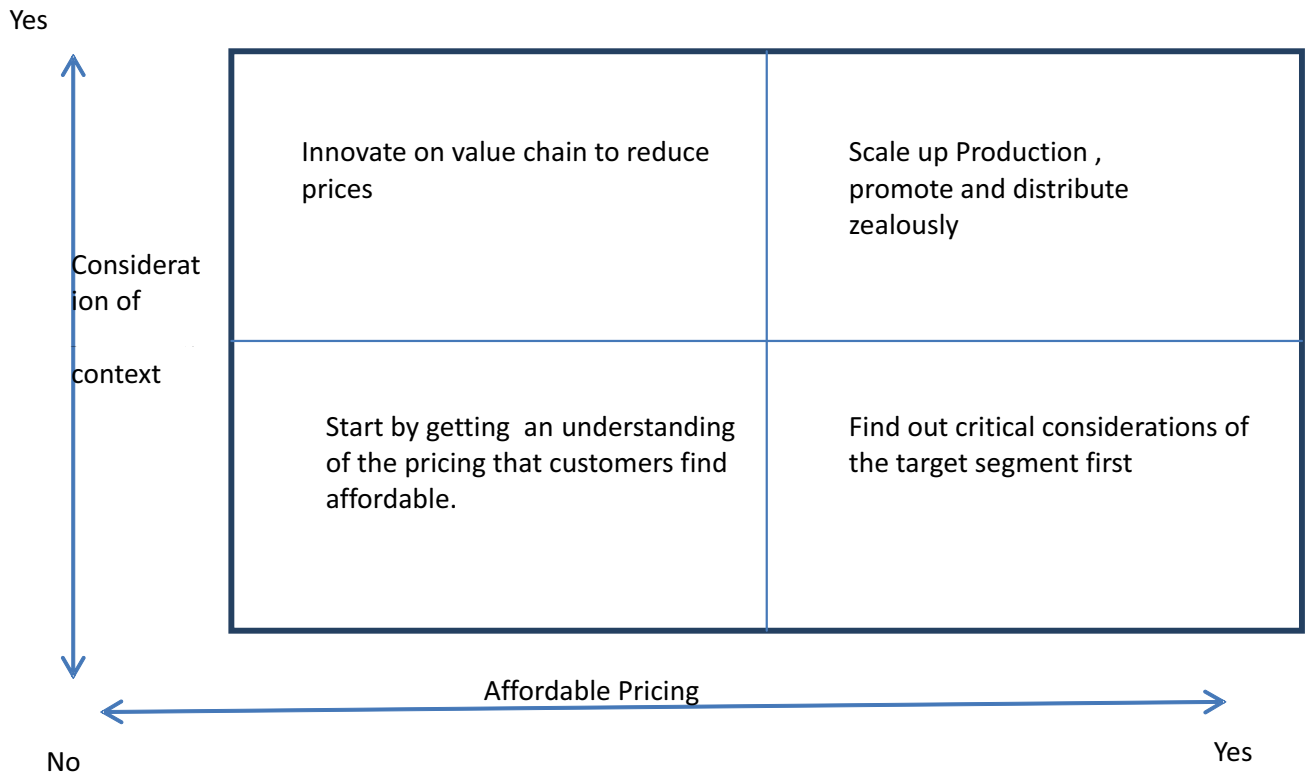

Source: Kaushik Mukerjee (2012)

Public - private partnership is seen to be effective Innovation to meet the frugal needs of the developing world, to develop the unique solutions to deliver the core concept of any product is termed as frugal product innovation. The six principles or pillars of frugal engineering efforts are robustness, portability, defeaturing, leapfrog technology, mega scale production, and service ecosystems. (Kumar \& Puranam 2012)

Housing is considered to be the single largest expenditure in a household, where the proportion of monthly investment for an average household ranges from thirty percent to fifty percentage or more in a household for the individual at the bottom of the economic pyramid. Even small percentage changes in affordability will have considerably large impact on overall well being especially at the bottom of the economic pyramid. The concept of affordability is not a single concept but an assimilation of issues- the distribution of housing prices, the distribution of housing quality, distribution of income, the ability of households to borrow, public policies affecting housing markets, conditions that affect new housing, choices that people make about how much housing to consume in relation to other goods. (Quigley and Raphael-2004). A successful in delivering affordable housing solutions and addressing complex social needs. In the process the four common barriers are funding barriers (lack of funds or uncertainty with tax credits); partner barriers (conflict with partners); community barriers (affordable housing needs by the community) and government barriers (mandates or opposition).It is found that leaders of successful collaborations are characterised by emotional and social competencies which lead them to the success. (Madden 2011). Government intervention is seen as necessary in Australian studies on necessity of providing affordable homes to the poor. It is stated from the studies that the provision of housing alone does not result in increase in overall well being of the citizens. Two options are suggested to be adopted as per the study, namely addressing people's impoverishment, but leaving housing market the same and increasing the supply of affordable housing that poor people can access, but not addressing the issue of relative poverty. The concept of addressing people's basic needs and eradicating poverty are seen to have more sustainability in addressing housing solution and overall well being. ( Parsell and Marston 2012) 
$3 \quad$ Analysing Demand and supply Factors for the Bottom of the Economic Pyramid

3.1 The following analysis was conducted to unearth the core concepts of affordable housing relevant with respect to both demand and supply side of affordable housing as revealed from the literature review. The Supply side factors are affordability and Building value chain with frugal engineering. The demand side comprises of critical considerations of the customers as listed below.

Exhibit No: 4 Analysing critical considerations regarding Affordability, Critical Customer considerations and Frugal Engineering

\begin{tabular}{|l|l|}
\hline \multicolumn{2}{|c|}{ A - Affordability } \\
\hline \multicolumn{1}{|c|}{ Determinant variables } & \multicolumn{1}{c|}{ Description } \\
\hline Distribution of housing prices & $\begin{array}{l}\text { Uneven \& Volatile (have risen around } 100 \% \\
\text { across the country on an average as per NHB } \\
\text { data Residex) }\end{array}$ \\
\hline Distribution of housing quality & Comparatively Higher in Private \\
\hline Distribution of income & $\begin{array}{l}\text { Uneven with Gini Coefficient of 33.9 as in } \\
2010 *\end{array}$ \\
\hline Ability of households to borrow & $\begin{array}{l}35 \% \text { in lower income category compared to } \\
\text { more than 50\% in middle to high income } \\
\text { category ** }\end{array}$ \\
\hline $\begin{array}{l}\text { Public policies affecting housing } \\
\text { markets }\end{array}$ & $\begin{array}{l}\text { External Commercial Borrowing approved } \\
\text { by National Housing Board }\end{array}$ \\
\hline $\begin{array}{l}\text { How much consumption on } \\
\text { housing in relation to other goods. }\end{array}$ & $\begin{array}{l}\text { Government directive for loan eligibility } \\
\text { earmarks not more than 30\% of Average } \\
\text { Monthly Family income to be paid towards } \\
\text { EMI }\end{array}$ \\
\hline
\end{tabular}




\begin{tabular}{|c|c|}
\hline \multicolumn{2}{|c|}{ B - Critical considerations of customers } \\
\hline Determinant variables & Description \\
\hline Location & $\begin{array}{l}\text { Affordable housing Projects located } \\
\text { typically } 25 \text { to } 30 \text { Kilometres from the city } \\
\text { centre }\end{array}$ \\
\hline Safety & Present in Private projects \\
\hline Sanitation & $\begin{array}{l}\text { More emphasised and maintained in Private } \\
\text { projects }\end{array}$ \\
\hline Access to drinking water & $\begin{array}{l}\text { Perennial issue in Urban areas for all income } \\
\text { segments }\end{array}$ \\
\hline Financial Inclusion & $\begin{array}{l}\text { Access to formal banking system present in } \\
\text { case of Affordable housing, dependence on } \\
\text { Microfinance seen more in low income } \\
\text { housing and slum rehabilitation }\end{array}$ \\
\hline Reasonable price & $\begin{array}{l}\text { National Housing board (NHB) specifies the } \\
\text { price of a single unit not to exceed } 30 \text { lakhs }\end{array}$ \\
\hline Ease of paperwork & $\begin{array}{l}\text { Initiatives such as Aadhar from UIDAI } \\
\text { helping in bringing Bottom of the Pyramid } \\
\text { Population into mainstream by giving } \\
\text { identity and access to formal systems } \\
\text { thereby reducing exploitation }\end{array}$ \\
\hline $\begin{array}{l}\text { Social inclusion and community } \\
\text { activities }\end{array}$ & $\begin{array}{l}\text { Seen to Increase with access to Affordable } \\
\text { housing }\end{array}$ \\
\hline \multicolumn{2}{|c|}{ C - Frugal Innovation - Building a new value chain } \\
\hline Determinant variables & Description \\
\hline Robustness & $\begin{array}{l}\text { Adaptability of affordable housing to huge } \\
\text { variations in demand and supply }\end{array}$ \\
\hline Portability & Need to Transport goods to rural and remote \\
\hline
\end{tabular}

* World Bank survey

**John Long LaSalle research

A primary survey was conducted to analyse the critical considerations of customers regarding affordable housing for the bottom of the Economic pyramid among 150 respondents to unearth the factors relevant to affordable housing in the critical factors (KYC) considered. The variables under study are Location, Civic Amenities, Easy Finance availability, Easy regulations, Affordable Price and Social Inclusion.
These variables are rated by the respondents on a semantic differential scale (7 point scale ).The following measures are unearthed from the primary data using SPSS Software to achieve the research objectives.

From the above analysis, the primary factors relevant to the study and relevant in terms of affordable housing for the Bottom of the Economic Pyramid are Easy Finance and Affordable Price. So the Primary Factors are related to the "Affordability factor ".The secondary factors affecting affordable housing at 
the Bottom of the Pyramid are social inclusion and Easy regulations. The findings from the primary survey reemphasises the concept that the most important factor driving demand in the affordable housing sector for the bottom of the economic pyramid is Affordable Price and availability of finance.

\section{Kaiser-Meyer-Olkin measure of sampling adequacy:}

" Range of 0.5 to 1.00 is acceptable for validity of factor analysis.

\section{Rotated factor matrix:}

" Identify variables having highest values and Group them as relevant number of factors.

\section{Exhibit No:5 KMO and Bartlett's Test}

\begin{tabular}{|c|c|c|}
\hline \multicolumn{2}{|c|}{$\begin{array}{c}\text { Kaiser-Meyer-Olkin Measure of } \\
\text { Sampling Adequacy. }\end{array}$} & .783 \\
\hline $\begin{array}{c}\text { Bartlett's Test of } \\
\text { Sphericity }\end{array}$ & Approx. Chi Square & 237.027 \\
\cline { 2 - 3 } & df & 15 \\
\cline { 2 - 3 } & Sig. & .000 \\
\hline
\end{tabular}

Source: Primary Data

Exhibit No:6 Rotated Factor Matrix(a)

\begin{tabular}{|l|r|r|}
\hline & \multicolumn{2}{|c|}{ Factor } \\
\hline Location & 1 & 2 \\
Civic_Amenities & .178 & .492 \\
Easy_Finance & .465 & .452 \\
Easy_Regulations & .649 & .206 \\
Affordable_Price & .576 & .504 \\
Social_Inclusion & .753 & .150 \\
\hline
\end{tabular}

Extraction Method: Principal Axis Factoring. Rotation Method: Varimax with Kaiser Normalization.

Exhibit No:7 Factor Score Coefficient Matrix

\begin{tabular}{|l|r|r|}
\hline & \multicolumn{2}{|c|}{ Factor } \\
\hline & \multicolumn{1}{|c|}{1} & \multicolumn{1}{|c|}{2} \\
\hline Location & -.028 & .211 \\
Civic_Amenities & .104 & .176 \\
Easy_Finance & .292 & -.053 \\
Easy_Regulations & .225 & .204 \\
Affordable_Price & .486 & -.159 \\
Social_Inclusion & -.167 & .528 \\
\hline
\end{tabular}

Extraction Method: Principal Axis Factoring.

Rotation Method: Varimax with Kaiser Normalization.
From the above analysis, the primary factors relevant to the study and relevant in terms of affordable housing for the Bottom of the Economic Pyramid are Easy Finance and Affordable Price. So the Primary Factors are related to the "Affordability factor ".The secondary factors affecting affordable housing at the Bottom of the Pyramid are social inclusion and Easy regulations. The findings from the primary survey reemphasises the concept that the most important factor driving demand in the affordable housing sector for the bottom of the economic pyramid is Affordable Price and availability of finance.

\section{Public - Private - Partnership (PPP) - A Boon to Affordable housing}

Madden (2011) says in the study that the practical application to reach the ultimate beneficiary in the affordable housing segment is made viable through successful public and private partnership where the leaders from the private sector have to develop strong emotional competencies (Initiative, Optimism, Adaptability, Transparency) and social competencies (Service, Conflict Management, Developing others, Empathy). Bratt (2008) in the study on federal initiatives in USA in housing states that public housing authorities have to work in tandem with private sector to facilitate resources for affordable housing.The effective leveraging of the following factors will result in greater benefits of PPP Model in affordable housing in India

\section{Land Availability}

- Effective use of available Government land

- Land parcels currently in possession can be used for development, thereby reducing the cost of land.

- Government can enter into joint ventures with developers with land as equity

Land Banking

- Purchase of large strips by State Governments /Agencies

" Distribution of land to private developers through a transparent process

\section{FSI}

- Relaxation of FSI norms to reduce per flat land cost 
- FSI is an effective tool to provide a cashless subsidy to builders

Cross Subsidization

- Joint development of MIG, LIG and EWS flats - MIG to subsidize others

- Built-up space covering LIG and EWS to be sold / rented by Government agency; developer can be allowed to sell MIG flats at market rates

Redevelopment / Rehabilitation

- Increasing availability of prime land by redevelopment/rehabilitation

\section{Improved Financing}

- A joint pool of public and private funds is likely to be more effective and efficient in financing development projects.

- The government can form development consortiums with private developers and guarantee bank loans provided by such consortiums, thereby reducing borrowing costs.

- Access to lower cost of capital - Relaxation of ECB norms for housing companies Increase in income tax ceiling on housing loans will reduce post tax cost of capital for borrowed

- Increase support to State Governments to engage in PPP projects

- Housing as a priority sector - Increase current limits on interest subsidies from INR 2 million to INR 4 million

\section{Lower Costs}

Single window approval for projects

- Delays incurred in project approvals result in substantial cost overruns.

- A single window will help reduce delays and contain costs

- Reduction in approval related costs

Subsidizing construction costs

- Reduction / exemption / deferment of taxes and duties on construction materials

- Subsidy to developers for R\&D in new low cost materials and technologies

- Subsidy to developer in view of employment generated

- Lower cost of borrowing for development of affordable housing projects - can be achieved if Government agencies have a participatory interest in the project and guarantee the loans
Sales Tax and Stamp Duty

- Exemption from sales tax and reduction in stamp duty

\section{Connectivity and Infrastructure}

Development of urban infrastructure

- PPP projects for accelerated urban infrastructure

- Metro rail, Inter-city highways, Mono rail

- Increase budgetary focus on urban infrastructure

- Increase support to State Governments to engage in PPP projects

Integrated Townships

- Joint developers with private players Development of infrastructure and residential space

- Planned expansion of city limits

Development of Satellite Towns

- Upfront infrastructure development around major cities a pre-requisite for planned development of satellite towns

- Mumbai and NCR have successfully developed satellite towns, which other cities can emulate

\section{Others}

Profitability of developers and housing finance companies

- 80 IB benefits for all approved affordable housing projects and developers

- Extension of 80 IB benefits for housing finance companies lending to LIG and EWS lenders

Special focus on EWS segment

- Significantly higher Government involvement and subsidiaries are required to provide equitable housing for EWS segment

- Innovative cross-subsidization schemes, extensive subsidies and suitable credit delivery mechanisms needed to address the specific challenges of EWS segment

\section{Process Innovations in affordable housing at the bottom of the economic pyramid}

Brian Rogal (2006) in the study on affordable housing challenges in the US describes the concept of subsidised housing practised in the 
country. The house residents typically occupied by low -to-moderate income families are required to pay 30 percentage of their income towards housing while the government subsidises the rest of the money towards providing housing solutions. Such a model can be replicated for government initiatives slum rehabilitation initiatives in urban India.

The challenge of meeting urbanisation needs is reflected in the fact that $15 \%$ of urban population in India at the Bop lives in slums without proper sanitation or water supply for years. There is an increasing shift towards urbanisation, as more population occupy urban areas in search of jobs and increased living conditions. This urban population is seen to have a median age of 18- 30, reflecting the demographic dividend. Further the birth rates in the country are increasing a trend which will result in increase in housing units for decades. The challenge is to meet the frugal needs of this segment with frugal innovation in affordable housing.

To meet the challenge, the financial needs of the urban poor needs to be met effectively. For successful migration of this population from the unorganised microfinance sector to more organised banking sector, needs KYC (Know Your customer)initiatives based on technology like Aadhaar which also propagates Saral Money Bank accounts for the poor.

In studying the initiatives of government sector, it is seen that slum rehabilitation invites are only partly successful as the location of housing units are remote form areas of employment of the slum dwellers, thereby making it a deterrent to their overall well being. There is trend of the slum dwellers renting out the affordable housing unit for additional income, whereas the rightful occupants go back to their slums.

\section{Conclusion}

The Bottom of the Economic Pyramid concept talks about deriving profitability from targeting the lower income population. It is seen that the Private firms which engage in Affordable housing is not usually for pure profit consideration but an initiative rooted in social responsibility. Frugal product innovation, which has been successful in products like cell phones and water filter, if adapted to the affordable housing segment in urban areas, will result in more new entrants in the industry which will ultimately become a win - win situation for all the players and increase value added for the customers. The current studies suggest that exclusion pertains to not offering consumers the products required by them as in the case of housing and that increased government intervention can provide lasting solutions to the Bottom of the Economic Pyramid (Jaiswal, 2007; Karnani, 2007).Eradicating poverty from the grass roots comprise a more lasting solution than providing more units in affordable housing, which can fall into wrong hands. (Parsell and Marston, 2012)

\section{References}

1. Bratt, Racheal," Viewing Housing Holistically: The Resident-Focused Component of the Housing-Plus Agenda." Journal of the American Planning Association, Vol. 74, Issue 1, pp.100-110 (2008)

2. GINI Index (2013) Retrieved from http://data.worldbank.org/indicator/SI.PO V.GINI as on 12th May 2013

3. India Brand Equity Foundation (2012) "Affordable housing in India: Budding, Expanding, Compelling" Retrieved from http://www.ibef.org/download/Affordabl e-Housing-in-India-24072012.pdf as on 12th May 2013

4. John Long laselle (2012)," Affordable Housing In India: An Inclusive Approach to Sheltering the Bottom of the Pyramid " $\mathrm{R}$ e $\mathrm{t} \mathrm{r}$ i e e d f r o m http://www.joneslanglasalle.co.in/Resear chLevel1/Affordable_Housing_in_India_ 2012.pdfas on 12th May 2013 
5. Karnani,Aneel,"The mirage of marketing to the Bottom of the Economic Pyramid: How the private sector can help alleviate poverty ",California management Review ,Vol 49,Issue 4,pp. 90-111 (2007)

6. KPMG In INDIA ( 2010),"Affordable Housing - A key growth driver in the real estate sector?" Retrieved from http://www.kpmg.com/IN/en/IssuesAndI nsights/ThoughtLeadership/Affordable Housing.pdf as on 12th May 2013.

7. Kumar, AnandJaiswal, "Fortune at the Bottom of the Economic Pyramid: An alternate perspective" Research and publications, Indian Institute of management, Ahmadabad. (2007) ;Retrieved as on 10th March, 2012 from http://www.iimahd.ernet.in/publications/ data/2007-07-13Jaiswal.pdf

8. Kumar, Nirmalya.,\&Puranam, Phanish," Frugal Engineerring :An Emerging Innovation Paradigm", Ivey Business Journal, Vol. 76, Issue 2, p14-16(2012)

9. Madden, Jennifer.R," Overcoming collaboration barriers in Affordable Housing Public- Private Partnerships" Academy of Management Annual Meeting Proceedings, pp.1-6(2011)
10. Mukerjee, Kaushik ,"Frugal Innovation :The Key to penetrating emerging markets ",Ivey Business Journal, Vol. 76, Issue 4, p1-3 (2012)

11. National Housing Board (2012) ," External Commercial Borrowing (ECB) for Low Cost Affordable Housing Projects", Retrieved from http://www.nhb.org.in/Whats_new/ECBAPPLICATION-2012.pdf as on 12th May 2013

12. Parsell, Cameron \& Marston, Greg," Beyond the 'At Risk' Individual: Housing and the Eradication of Poverty to Prevent Homelessness." Australian Journal of Public Administration, Vol. 71, Issue 1, pp.33-44 (2012)

13. Prahalad, C. K .,\& Hart, S. L.,"The Fortune at the Bottom of the Economic Pyramid" Strategy+Business, Vol.26, pp. 1-14.

14. Quigley, John M. \& Raphael, Steven, "Is Housing Unaffordable? Why Isn't It More Affordable?" Journal of Economic Perspectives, Vol. 18 Issue 1, pp.191-214 (2004)

15. Rogal, Brian," Affording Affordable housing ", Journal of Property Management, Vol. 71 Issue 6, pp.18-22 (2006) 